\title{
HIV-1 Envelope gp41 Is a Potent Inhibitor of Chemoattractant Receptor Expression and Function in Monocytes
}

\author{
Hirotsugu Ueda, ${ }^{\star}$ O.M. Zack Howard, ${ }^{\S}$ Michael C. Grimm, ${ }^{\star}$ Shao-bo Su, ${ }^{\star}$ Wanghua Gong,,${ }^{\S}$ Gerald Evans, ${ }^{\S}$ \\ Francis W. Ruscetti, ${ }^{\ddagger}$ Joost J. Oppenheim, ${ }^{\star}$ and Ji Ming Wang ${ }^{\star}$ \\ *The Laboratory of Molecular Immunoregulation and ${ }^{\ddagger}$ The Laboratory of Leukocyte Biology, Division of Basic Sciences, National \\ Cancer Institute, Frederick Cancer Research and ${ }^{\S}$ Development Center; Intramural Research Support Program and AIDS Vaccine \\ Program, SAIC Frederick, National Cancer Institute, Frederick Cancer Research and Development Center, Frederick, \\ Maryland 21702-1201
}

\begin{abstract}
HIV-1 uses CD4 and chemokine receptors as cofactors for cellular entry. The viral envelope transmembrane protein gp41 is thought to participate in viral fusion with $\mathrm{CD}^{+}$ cells. We investigated whether gp41 interacts with chemokine receptors on human monocytes by testing its effect on the capacity of cells to respond to chemokine stimulation. Monocytes preincubated with gp41 of the MN strain showed markedly reduced binding, calcium mobilization, and chemotaxis in response to a variety of chemokines as well as to the bacterial peptide fMLP. This generalized inhibition of monocyte activation by chemoattractants required the presence of CD4, since the effect of gp41 was only observed in $\mathrm{CD}^{+}$monocytes and in HEK293 cells cotransfected with chemokine receptors and an intact CD4, but not a CD4 lacking its cytoplasmic domain. Confocal microscopy showed that gp41 caused internalization of CXCR4 in HEK293 cells provided they were also cotransfected with intact CD4. In addition, pretreatment of monocytes with protein kinase $\mathrm{C}$ inhibitors partially reversed the inhibitory effect of gp41. Thus, gp41, which had not previously been implicated as interacting with HIV-1 fusion cofactors, downregulates chemoattractant receptors on monocytes by a CD4-dependent pathway. (J. Clin. Invest. 1998. 102:804812.) Key words: HIV-1 - gp41 - chemokines • receptors • suppression
\end{abstract}

\section{Introduction}

The envelope glycoprotein gp160 of HIV-1 is enzymatically cleaved during the fusion process, yielding two mature pro-

The content of this publication does not necessarily reflect the views or policies of the Department of Health and Human Services, nor does mention of trade names, commercial products, or organization imply endorsement by the U. S. Government.

Address correspondence to J.M. Wang, Laboratory of Molecular Immunoregulation, Division of Basic Sciences, National Cancer Institute, Frederick Cancer Research and Development Center, Building 560, Room 31-40, Frederick, MD 21702-1201. Phone: 301-846-1347; FAX: 301-846-7042; E-mail: wangji@mail.ncifcrf.gov

Received for publication 5 March 1998 and accepted in revised form 22 June 1998.

The Journal of Clinical Investigation

Volume 102, Number 4, August 1998, 804-812

http://www.jci.org teins, the transmembrane gp41 and the surface gp120 $(1,2)$. HIV-1 infection is initiated by high-affinity binding of gp120 to CD4, which was identified as the primary receptor for HIV-1 (3, 4). Recently, members of the seven-transmembrane chemokine receptor superfamily have been identified as essential cofactors for HIV-1 entry (5), and HIV-1 cell-type tropism seems to be dictated by chemokine receptor usage. After the binding of the envelope gp120 to CD4, the chemokine receptors, CXCR4 for T lymphotropic and CCR5 for monotropic HIV-1, may either be bound by an epitope exposed on gp120, or be recruited by gp120/CD 4 complex. The interaction between gp120 and coreceptors then induces a structural change in gp41 culminating in a fusogenic state (6). Gp41 is thought to mediate fusion between viral and cellular membranes $(7,8)$ by the insertion of the hydrophobic amino terminus into the plasma membrane. The identity of the cell surface molecules targeted by gp41 has not been elucidated.

Although HIV-1-induced T lymphocyte suppression and depletion are central features of the immunosuppression in AIDS patients, monocyte macrophages are also targets of the virus infection. Earlier studies demonstrated that monocytes from AIDS patients exhibited a significantly compromised capacity to migrate in response to several chemotactic factors, including activated complement component C5a, the bacterial peptide fMLP, and undefined lymphocyte-derived chemotactic factors (9). Although a number of observations have implicated gp120 in these events $(9,10)$, several lines of evidence showed that gp41 also may have multiple effects on the host immune system. Soluble gp41 has been shown to induce the production of proinflammatory cytokines such as TNF $\alpha$ and IL-1 (11-15) and to increase the activity of nitric oxide synthase in mononuclear phagocytes and glial cells, thus contributing to HIV-1 infection-associated dementia (16). Gp41 was also reported to suppress human lymphocyte proliferation (17) and to favor a Th2 type immune response by inducing IL-10 production in monocytes (18). Peptides derived from an immunosuppressive domain conserved in animal and human retroviral envelope proteins, which is also present in gp41 of HIV-1, are potent inhibitors of lymphocyte proliferation in response to mitogens and monocyte migration induced by chemoattractants $(19,20)$. Since chemokines are important mediators of host defense with the capacity to attract and activate different leukocyte subpopulations in the course of inflammatory and immune responses $(21,22)$, we postulated that gp41 may contribute to the antiinflammatory and immunosuppressive effects of HIV-1 by interfering with chemokinereceptor interactions. Our study shows that prior exposure to gp41 inhibited the monocyte response to a variety of chemokines as well as to the bacterial fMLP by downregulating the cell surface expression of their receptors in a CD4-dependent manner. 


\section{Methods}

Reagents and cells. Recombinant (r) gp41 (strain MN) and recombinant soluble CD4 were purchased from Intracel (Cambridge, MA). At the highest concentration (100 nM) tested, the gp41 preparations had $<0.2 \mathrm{ng} / \mathrm{ml}$ of endotoxin activity. The gp $41 \mathrm{MN}$ used in the study was more than $98 \%$ pure as confirmed by SDS-PAGE and silver staining (H. Ueda, data not shown). Monoclonal anti CD4 antibodies were purchased from Biogenesis (Poole, UK). Recombinant chemokines were purchased from PeproTech (Rocky Hill, NJ). Radioiodinated chemokines were purchased from Dupont New England Nuclear (Boston, MA). Human peripheral blood monocytes were isolated from leukapheresis packs (National Institutes of Health Clinical Center, Transfusion Medicine Department, Bethesda, MD) enriched for mononuclear cells by using isoosmotic Percoll gradient as previously described (23). Neutrophils were isolated from granulocyte enriched blood packs with Dextran sedimentation as described (23). The purity of the cell preparations was examined by morphology and was $>90 \%$ for monocytes and $>95 \%$ for neutrophils. The CCR5-transfected HEK 293 cells are a kind gift from Dr. P. Gray (ICOS Corp., Seattle, WA). CXCR4/Fusin cDNA was isolated in this laboratory and was transfected into 293 cells as described (24). The viability of monocytes or HEK 293 cells before and after gp41 treatment was examined by trypan blue exclusion and was $>95 \%$ alive after up to $18 \mathrm{~h}$ treatment at $37^{\circ} \mathrm{C}$.

Flow cytometric analysis of intracellullar calcium mobilization and CCR5 expression. The $\mathrm{Ca}^{2+}$ mobilization in monocytes was measured by FACS analysis (courtesy of Ms. L. Finch, SAIC Frederick, National Cancer Institute-Frederick Cancer Research and Development Center). Monocytes $\left(10^{7}\right)$ loaded with Indo-1 were treated with gp41 $(\mathrm{MN}, 25 \mathrm{nM})$ or medium alone for $60 \mathrm{~min}$ at $37^{\circ} \mathrm{C}$. The loaded cells were washed and resuspended in fresh medium. After stimulation with chemokines $(10 \mathrm{nM})$ or fMLP $(10 \mathrm{nM})$, the bound/free ratio of the dye was continuously recorded using EPICS 753 (Coulter Corp., Miami, FL). The values in the figure are percentage of responding cells.

The change of surface expression of CCR5 on monocytes was monitored by FACS analysis (courtesy of Ms. L. Finch). Monocytes $\left(1 \times 10^{6}\right)$ were preincubated with medium alone, macrophage inflammatory protein (MIP)-1 $1 \beta^{1}(120 \mathrm{nM})$, gp41 (MN, $\left.5 \mathrm{nM}\right)$, anti-CD4 mAbs A6 $(10 \mu \mathrm{g} / \mathrm{ml})$, PMA $(1 \mathrm{ng} / \mathrm{ml})$, or anti-CD14 $(10 \mu \mathrm{g} / \mathrm{ml})$ for 60 min at $37^{\circ} \mathrm{C}$. After incubation, the cells were washed and stained with control rabbit serum or rabbit polyclonal anti-CCR5 antiserum (kind gift from Dr. Philip M. Murphy, National Institutes of Health, Bethesda, MD), followed by FITC anti-rabbit antibody. Stained cells were analyzed on EPICS profile (Coulter Corp.).

Chemotaxis assays. Chemotaxis assays were performed using a 48-well chemotaxis chamber (Neuroprobe, Cabin John, MD) as described previously $(23,24)$. Chemoattractants were placed in the lower wells of the chamber, $50 \mu \mathrm{l}$ cell suspension $\left(2 \times 10^{6} / \mathrm{ml}\right.$ for monocytes or neutrophils, $1 \times 10^{6} / \mathrm{ml}$ for HEK 293 cells) were placed in the upper wells. The upper and lower wells were separated by a $5-\mu \mathrm{m}$-pore size polycarbonate filter. For HEK 293 cells the $10-\mu \mathrm{m}-$ pore size filter was precoated with collagen IV as described (24). After incubation ( $90 \mathrm{~min}$ for monocytes, $60 \mathrm{~min}$ for neutrophils, $300 \mathrm{~min}$ for 293 cells) at $37^{\circ} \mathrm{C}$, the filters were removed and stained; the cells migrated across the filters were counted after the samples were coded. Results were calculated as the mean $( \pm \mathrm{SD})$ number of migrated cells in three high-powered light microscopy fields in triplicate samples. The chemotaxis index (CI) represents the fold increase in cell migration in response to chemoattractants versus medium control. In chemotaxis inhibition experiments, monocytes (or neutrophils) and HEK 293 cells transfected with chemokine receptors were

1. Abbreviations used in this paper: $\mathrm{MCP}$, monocyte chemotactic protein; MIP, macrophage inflammatory protein; $\mathrm{PKC}$, protein kinase $\mathrm{C}$; SDF, stromal cell-derived factor. preincubated with chemoattractants or gp 41 for 30 or $60 \mathrm{~min}$ at $37^{\circ} \mathrm{C}$, then washed three times with PBS. The cell migration in response to various chemoattractants was then assessed and computed as described above. After subtraction of background migration (in response to medium), the percentage inhibition of chemotaxis to a given chemoattractant was calculated by the formula: $(1-$ migration of cells preincubated with gp41/migration of cells preincubated with medium) $\times 100$.

Binding assays. Binding assays were performed by preincubating duplicate samples of monocytes $\left(2 \times 10^{6}\right)$ or chemokine receptor transfected 293 cells $\left(1 \times 10^{6}\right)$ with different concentrations of gp41 for $60 \mathrm{~min}$ at $37^{\circ} \mathrm{C}$ in a volume of $200 \mu \mathrm{l} / \mathrm{sample}$ of binding medium (RPMI 1640, $1 \%$ BSA, $5 \mathrm{mM}$ Hepes, and $0.05 \% \mathrm{NaN}_{3}$ ). $0.12 \mathrm{nM}$ radiolabeled chemokines was then added to each sample. To parallel duplicate samples, different concentrations of gp41 or unlabeled chemokines (as control) were added simultaneously with radiolabeled chemokines. After incubation at room temperature for $40 \mathrm{~min}$, the cells were centrifuged through a $10 \%$ sucrose/PBS cushion and the cellassociated radioactivity was measured in a gamma counter. The percentage inhibition of chemokine binding on monocytes after treatment with gp41 was calculated by the formula: $(1-$ counts per minute associated with cells in the presence of gp41/counts per minute associated with cells with medium alone $) \times 100$.

To determine the change in the number of binding sites and affinity for a given chemokine, cells were preincubated with or without gp41 (5 nM) for $60 \mathrm{~min}$ at $37^{\circ} \mathrm{C}$. The duplicate monocyte samples were then incubated with $0.12 \mathrm{nM}$ radiolabeled chemokines in the presence of increasing concentrations of unlabeled chemokines. The cells were pelleted after incubation for $40 \mathrm{~min}$ at room temperature and measured for radioactivity. The binding data were analyzed with a Macintosh computer program LIGAND (Dr. P. Muson, Division of Computer Research and Technology, National Institutes of Health, Bethesda, MD).

Confocal microscopy. Internalization of CXCR4/Fusin by pretreatment of $\mathrm{CD}^{+} / \mathrm{CXCR} 4^{+} \mathrm{HEK} 293$ cells with gp41 and anti-CD4 antibody was examined with confocal microscopy. HEK293 cells expressing CXCR4 and intact $\mathrm{CD} 4$ were pretreated for $3 \mathrm{~h}$ at $37^{\circ} \mathrm{C}$ with gp41 $(25 \mathrm{nM})$ or anti-CD4 mAb $(\mathrm{A} 6 ; 5 \mu \mathrm{g} / \mathrm{ml})$. The cells were centrifuged onto slides and permeabilized. The slides were then stained with an anti-CXCR4/fusin mAb (12G5) followed by incubation with FITC-labeled goat anti-mouse $\operatorname{IgG~F}\left(\mathrm{ab}^{\prime}\right)_{2}$ fragments. Slides were examined using a confocal laser scanning microscope (model 310; Carl Zeiss, Inc., Thornwood, NY). Nomarski, FITC (488 nm, green) and DAPI (ultraviolet $364 \mathrm{~nm}$, blue) images were prepared for each specimen and colored images were superimposed on Nomarski.

Statistical analysis. All experiments were performed at least three times and the results presented are either from a representative experiment or from a pool of experiments as indicated. The significance of the difference between experimental and control groups was analyzed with Student's $t$ test.

\section{Results}

Gp41 inhibits the monocyte response to chemokines and $f M L P$. We first asked whether gp41 had the capacity to suppress monocyte responses to chemokines. Recombinant gp41 of the MN strain over a wide range of concentrations (0.1-100 $\mathrm{nM})$ did not induce $\mathrm{Ca}^{2+}$ mobilization in human monocytes (data not shown). This gp41 also did not desensitize subsequent (within $100 \mathrm{~s}$ ) monocyte $\mathrm{Ca}^{2+}$ mobilization induced by chemokines or the bacterial fMLP (not shown). We therefore investigated whether a more prolonged incubation with gp41 could affect the monocyte response. As Fig. 1 shows, preincubation of monocytes with gp41 $(5 \mathrm{nM})$ for $1 \mathrm{~h}$ at $37^{\circ} \mathrm{C}$ significantly reduced the $\mathrm{Ca}^{2+}$ mobilization induced by $\mathrm{CC}$ chemokines MIP-1 $\alpha$ and RANTES as well as CXC chemokine 


\section{A. Cells treated with medium}

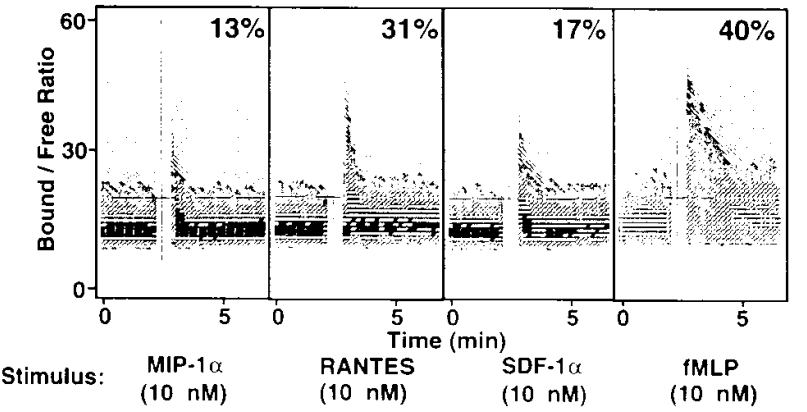

B. Cells treated with gp41 (MN, 5 nM)

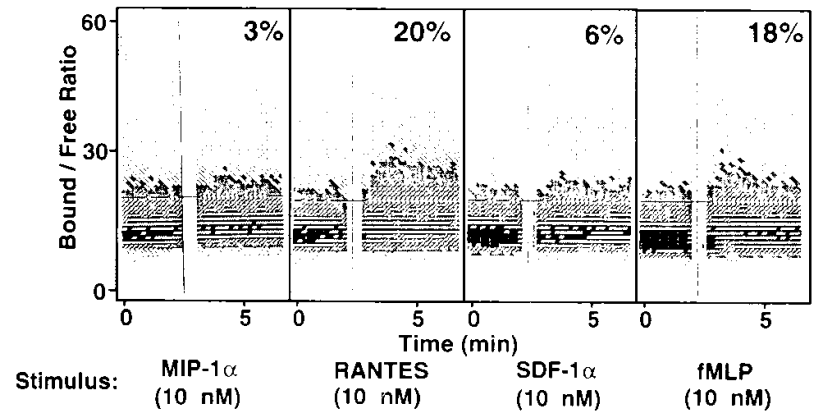

stromal cell-derived factor (SDF)-1 $\alpha(10 \mathrm{nM})($ Fig. $1 B)$. The $\mathrm{Ca}^{2+}$ mobilization in response to fMLP (Fig. $1 B$ ) and monocyte chemotactic protein (MCP)-1 (not shown) was also significantly reduced by preincubation of monocytes with gp 41 .

We next examined the effect of gp41 on the directional migration of monocytes induced by a variety of chemoattractants. Incubation of monocytes with gp $41(0.5 \mathrm{nM})$ for $60 \mathrm{~min}$ at $37^{\circ} \mathrm{C}$ markedly reduced their chemotactic response to $\mathrm{CC}$ chemokines that utilize various $\mathrm{CC}$ chemokine receptors including CCR5, as well as to SDF- $1 \alpha$, the ligand for CXCR4/ Fusin (Table I). The inhibition of monocyte migration by gp41 could also be demonstrated for fMLP, which utilizes a receptor structurally related to chemokine receptors. Gp41 itself did not induce significant migration of human monocytes and monocytes preincubated for only $30 \mathrm{~min}$ at $37^{\circ} \mathrm{C}$ with gp 41 did not show reduced migration in response to chemokines or fMLP (data not shown).

Since gp41 did not affect the chemotactic response of CD4 ${ }^{-}$neutrophils to fMLP or IL-8 (Table I), we investigated whether the inhibitory activity of gp41 required the presence of additional cellular molecules such as CD4, which are absent on neutrophils. Gp41 failed to inhibit the migration of CCR5transfected HEK 293 cells lacking CD4 in response to the ligand MIP-1 $\beta$ (data not shown). In contrast, CCR5/293 cells that were additionally transfected with $\mathrm{CD} 4$ migrated in response to MIP-1 $\beta$ and this migration was significantly inhibited when the cells were preincubated with gp41 (Table II). Preincubation of gp41 with a soluble CD4 significantly reduced the inhibitory effect of gp41 on monocyte migration induced by chemokines and fMLP (Table I). These observations suggest that the suppressive activity of gp41 on chemokine receptor-mediated cell migration requires binding to cell-associated $\mathrm{CD} 4$, while soluble $\mathrm{CD} 4$ interacts with and reduces the effect of gp41 on monocyte response to chemokines and fMLP.

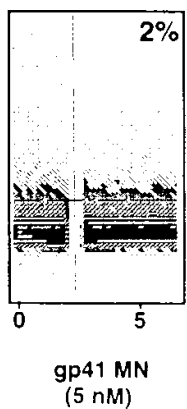

Figure 1. Effect of gp41 on calcium flux responses of monocytes to chemoattractants. Monocytes loaded with indo-1 were treated with gp41 (MN, $5 \mathrm{nM})$ or medium alone for $60 \mathrm{~min}$ at $37^{\circ} \mathrm{C}$. The cells were then stimulated with chemokines (10 nM), fMLP $(10 \mathrm{nM})$, or gp41 (MN, $5 \mathrm{nM})$, and bound/free ratio was continuously recorded. The values in the figure are percentage of responded cells. ( $A$ ) $\mathrm{Ca}^{2+}$ flux induced by various chemoattractants and gp41 in monocytes preincubated with medium. (B) Response of monocytes pretreated with gp41.

GP41 downregulates chemokine receptor expression on monocytes. In an effort to define the mechanism(s) of the suppressive effects of gp41 on monocyte responses to chemokines, we evaluated the consequences of exposure to gp41 on monocyte binding of chemokines. The direct effect of gp41 on chemokine binding was investigated by adding soluble gp41 and radiolabeled chemokines simultaneously to human pe-

Table I. Inhibition by gp41 (MN) of Monocyte Chemotaxis in Response to Chemokines and $f M L P^{*}$

\begin{tabular}{|c|c|c|c|c|}
\hline \multirow[b]{3}{*}{ Cell } & \multirow[b]{3}{*}{$\begin{array}{l}\text { Chemo- } \\
\text { attractants }\end{array}$} & \multicolumn{3}{|c|}{ Monocytes chemotaxis (chemotaxis index) } \\
\hline & & \multicolumn{3}{|c|}{ Cells preincubated with } \\
\hline & & Medium & $\begin{array}{c}\text { gp41 } \\
\text { (\% reduction) }\end{array}$ & $\begin{array}{l}\text { gp } 41+\mathrm{sCD} 4 \\
(\% \text { recovery })\end{array}$ \\
\hline \multirow{5}{*}{ Monocytes } & MIP-1 $\beta$ & 2.73 & $0.99(100)^{\ddagger}$ & $1.88(51)$ \\
\hline & RANTES & 2.35 & $1.06(96)^{\ddagger}$ & $1.45(30)$ \\
\hline & MCP-1 & 6.74 & $3.60(55)^{\ddagger}$ & $6.85(100)$ \\
\hline & SDF- $1 \alpha$ & 4.95 & $1.23(94)^{\ddagger}$ & $3.70(66)$ \\
\hline & fMLP & 12.38 & $5.80(58)^{\ddagger}$ & $8.35(39)^{\S}$ \\
\hline \multirow[t]{2}{*}{ Neutrophils } & IL-8 & 9.36 & $10.47(0)$ & 9.76 \\
\hline & fMLP & 7.45 & $8.36(0)$ & 8.00 \\
\hline
\end{tabular}

*Recombinant gp41 $(0.5 \mathrm{nM})$ was preincubated in the presence or absence of sCD4 $(10 \mathrm{nM})$ for $30 \mathrm{~min}$ at $37^{\circ} \mathrm{C}$, then was further incubated with monocytes for $60 \mathrm{~min}$ at $37^{\circ} \mathrm{C}$. After washing, the cell migration in response to chemokines $(10 \mathrm{nM})$ or fMLP $(10 \mathrm{nM})$ was determined. The chemotaxis index represents the fold increase in cell migration to chemoattractants versus medium (chemotaxis index $=1$ ). ${ }^{\ddagger} P<0.01$ (Student's $t$ test) compared with the migration of monocytes preincubated with medium alone. ${ }^{\S} P<0.01$ (Student's $t$ test) compared with the migration of monocytes preincubated with gp41 alone. 
Table II. Effect of gp 41 on CCR5/293/CD4 Cell Migration in Response to MIP-1 $\beta^{*}$

\begin{tabular}{lcccc}
\hline & \multicolumn{4}{c}{ Chemotaxis index (Mean \pm SE, \% inhibition) } \\
\cline { 2 - 4 } Chemoattractant & Medium & $\begin{array}{c}\text { gp41 } \\
(\mathrm{MN}, 25 \mathrm{nM})\end{array}$ & $\begin{array}{c}\text { Anti-CD4 } \\
(\mathrm{A} 6,10 \mu \mathrm{g} / \mathrm{ml})\end{array}$ & $\begin{array}{c}\text { Anti-CD4 } \\
(\mathrm{E} 9,10 \mu \mathrm{g} / \mathrm{ml})\end{array}$ \\
\hline
\end{tabular}

MIP-1 $(12 \mathrm{nM}) \quad 15.3 \pm 1.5 \quad 6.3 \pm 2.0(63)^{\ddagger} 7.8 \pm 1.1(52)^{\S} 6.9 \pm 0.8(38)^{\S}$

*CCR5/293 cells were transfected with CD4 and were preincubated for $10 \mathrm{~h}$ with gp41 (MN) or anti-CD4 antibodies at $37^{\circ} \mathrm{C}$. Cell migration in response to MIP-1 $\beta$ was then evaluated. The chemotaxis index represents the fold increase in cell migration in response to chemokine versus medium (chemotaxis index $=1$ ). ${ }^{\ddagger} P<0.05$ (Student's $t$ test) compared with the migration of monocytes preincubated with medium alone. ${ }^{\S} P<$ 0.01 .

ripheral blood monocytes. While all unlabeled chemokines (60-120 nM) showed the expected competition for binding by radiolabeled ligands (Fig. 2, horizontal lines), gp41 did not compete directly for binding sites with radiolabeled chemokines on monocytes or neutrophils (Fig. 2, hatched bars). However, when monocytes were preincubated with gp 41 at $37^{\circ} \mathrm{C}$ for $60 \mathrm{~min}$, they showed a significantly reduced capacity to bind chemokines (Fig. 2, A-E, shaded bars). The 50\% inhibitory concentration values for gp41 inhibition of monocyte binding of chemokines were in the pM range $(0.1,0.2,0.5,0.6$, and $0.4 \mathrm{nM}$ for MIP-1 $\beta$, MIP- $1 \alpha$, RANTES, MCP-1, and MCP-3 respectively), indicating a highly potent suppressive activity of gp41 on the monocyte expression of chemokine-binding sites. Consequently, preincubation of monocytes with gp 41 not only markedly inhibited their capacity to bind MIP-13, which uses exclusively CCR5 (25-27), but also inhibited their binding of MIP- $1 \alpha$ and RANTES which in addition use CCR1 $(28,29)$ and other C-C chemokine receptors $(21,22)$. Furthermore, the capacity of monocytes to bind ${ }^{125}$ I-MCP-1 and
${ }^{125}$ I-MCP-3 was also significantly inhibited by preincubation of the cells with gp41 (Fig. 2, $D$ and $E$ ), even though these chemokines have been reported to predominantly use CCR2B and/or CCR1 $(24,30,31)$. Thus, gp41 appears to desensitize a wide range of $\mathrm{CC}$ chemokine receptors. In contrast, preincubation with gp41 did not inhibit the neutrophil binding of the CXC chemokine IL-8, a potent chemotactic factor for neutrophils rather than monocytes (Fig. $2 \mathrm{~F}$ ), which is in agreement with a preferential suppression of monocyte response to chemokines by gp41 as seen in chemotaxis experiments.

The effect of gp41 on the cell surface expression of CCR5 on monocytes was analyzed and confirmed by using a specific anti-CCR5 antibody and FACS. A substantial proportion of human monocytes $(84 \%)$ expressed CCR5 on the cell surface (Fig. 3 A, shaded peak) and treatment of the cells at $37^{\circ} \mathrm{C}$ for 60 min with a native CCR5 ligand MIP- $1 \beta$ completely downregulated CCR5 expression (Fig. 3 B). When cells were treated with gp41 (5 nM, Fig. $3 C$ ) or an anti-CD4 mAb (Fig. 3 $D$ ), the surface expression of CCR5 was also downregulated to control levels, whereas an anti-CD14 mAb had no effect (Fig. $3 F)$. PMA, a protein kinase $\mathrm{C}$ (PKC) activator which has been reported to downregulate HIV-1 coreceptor (32), was used as a positive control and PMA markedly downregulated the expression of CCR5 (Fig. $3 E$ ). The opposite effect was obtained with a PKC inhibitor calphostin C. As Fig. $3 G$ shows, monocytes preincubated with calphostin $\mathrm{C}$ maintained a high-level expression of CCR5 on the cell surface after gp41 treatment. Furthermore, in ligand binding experiments, calphostin $\mathrm{C}$ and another PKC inhibitor, staurosporine, could partially maintain the expression of chemokine-binding sites for $\mathrm{CC}$ chemokines as well as CXC chemokine SDF-1 $\alpha$ (Table III). These results suggest that PKC-mediated cell signaling events were involved in the downregulation of a variety of chemokine receptors by gp41 on monocytes.

The effect of gp 41 is CD4 dependent. To directly visualize the localization of chemokine receptor after gp41 treatment, we used confocal microscopy of HEK293 cells overexpressing CXCR4 (CXCR4/293 cells). SDF-1 $\alpha$, which is a native ligand

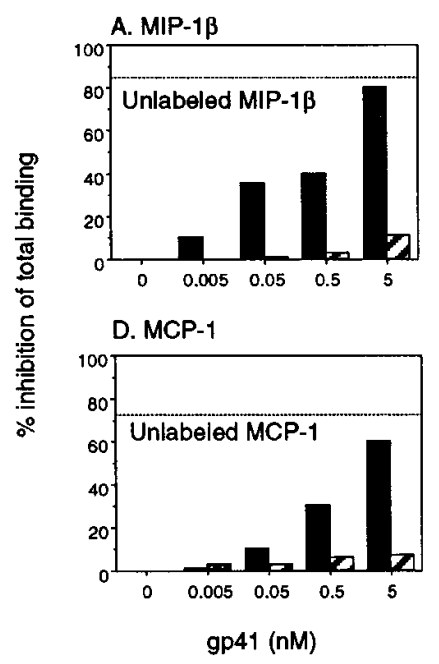

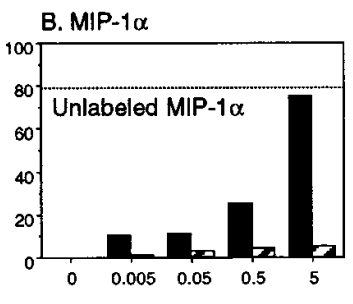

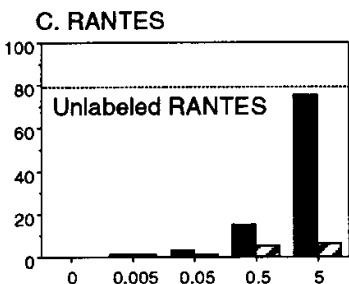

E. MCP-3

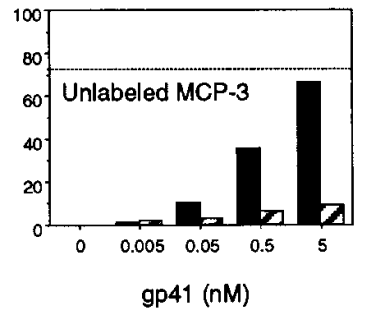

Figure 2. Effect of gp41 on the capacity of monocytes to bind chemokines. Monocytes were preincubated in duplicate with medium alone or different concentrations of gp41 (MN) for $60 \mathrm{~min}$ at $37^{\circ} \mathrm{C}$.

${ }^{125}$ I-labeled chemokines were added and the cultures were continued for $40 \mathrm{~min}$ at room temperature. The cells were then centrifuged through a sucrose cushion and measured for radioactivity. Direct competition experiments were performed in parallel by adding different concentration of gp41 simultaneously with ${ }^{125}$ I-labeled chemokines to duplicate monocyte samples. Unlabeled chemokines were used as control competitors. The cells were incubated at room temperature for 40

min and harvested. One of three representative experiments is shown. Shaded bars, percent reduction of monocyte binding for chemokines. Hatched bars, levels of direct competition with chemokines for binding by gp41. Horizontal lines, maximal level of direct competition of chemokine binding by unlabeled native ligands $(120 \mathrm{nM})$. $(A-E)$ Reduction of ${ }^{125} \mathrm{I}$-labeled CC chemokine binding to monocytes pretreated with gp41 (shaded bars) or direct competition by gp41 of chemokine binding (hatched bars). (F) Effect of gp41 on neutrophil binding of ${ }^{125}$ I-IL-8. 


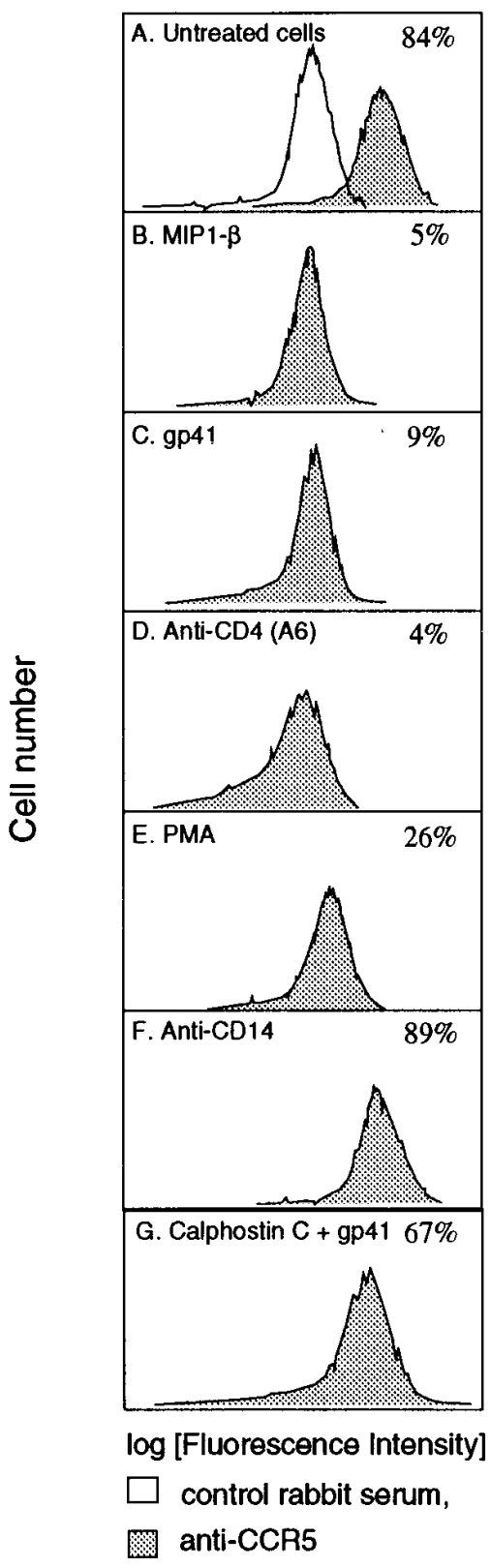

Figure 3. FACS analysis of CCR5 expression on human monocytes. Monocytes were preincubated with $(A)$ medium alone, $(B)$ MIP-1 $\beta$ $(120 \mathrm{nM}),(C) \mathrm{gp} 41$ $(\mathrm{MN}, 5 \mathrm{nM}),(D)$ antiCD4 mAb (clone A6, 10 $\mu \mathrm{g} / \mathrm{ml}),(E)$ PMA $(1 \mathrm{ng} /$ $\mathrm{ml})$, or $(F)$ anti-CD14 antibody $(10 \mu \mathrm{g} / \mathrm{ml})$ for 60 min. In $G$, monocytes were first treated with calphostin C (100 $\mathrm{ng} / \mathrm{ml}$ for $4 \mathrm{~h}$ at $37^{\circ} \mathrm{C}$ ), followed by $1 \mathrm{~h}$ incubation with $5 \mathrm{nM}$ gp41. After washing, cells were stained with control rabbit serum or rabbit polyclonal antiCCR5 antiserum (kind gift from Dr. Philip M. Murphy of National Institutes of Health, Bethesda, MD), followed by FITC-conjugated anti-rabbit $\operatorname{IgG}$ antibody. The percentage of cells positively stained with anti-CCR5 antibody is shown in each panel. Data are from one experiment out of three performed.

for CXCR4, caused internalization of CXCR4 in both $\mathrm{CD} 4^{+}$ and $\mathrm{CD}^{-}{ }^{-}$CXCR4/293 cells (Fig. 4, $B$ and $F$ ) as stained by an anti-CXCR4 mAb. Preincubation with gp41 caused marked internalization of CXCR4 (Fig. 4 C) in CXCR4/293 cells provided they were cotransfected with CD4, but not in CXCR4/ 293 cells lacking CD4 (Fig. $4 G$ ). Confocal microscopy also revealed that gp41 MN induced internalization of CCR5 in 293 cells transfected with CCR5 and CD4 (data not shown), in agreement with the results of FACS analysis of gp41-treated monocytes (Fig. 3). In addition, as observed in FACS analyses of CCR5 on monocytes, anti-CD4 antibody also caused downregulation from the cell surface and intracytoplasmic localization of CXCR4 in CXCR4/293 cells coexpressing CD4 (Fig. 4 $D)$. These observations further document the requirement of CD4 for gp41 to downregulate cell surface expression of chemokine receptors.

Gp41 has been reported to stimulate monocytes to produce cytokines and nitric oxide synthase suggesting that gp41 transduces signals and activates monocytes (11-15). We also showed in this study that gp41 downregulated chemokine receptors on monocytes by activating a PKC-mediated signaling pathway. Since the effect of gp41 on chemokine receptor expression was CD4 dependent, we investigated whether CD4 indeed could mediate signal transduction induced by gp41. We compared the suppressive effect of gp41 on CCR5/293 cells cotransfected with an intact CD4 or with a CD4 lacking its cytoplasmic tail (tailless). The binding capacity of the CCR5/293 cells transfected with intact CD4 was inhibited by gp41 or antiCD4 antibody (Table IV). In contrast, the ability of HEK 293 cells to bind MIP-1 $\beta$ could not be inhibited by preincubation of the cells with gp41 or anti-CD4 antibody if the cells expressed CCR5 and a tailless CD4. This suggests that CD4 is an active signal transducer rather than a passive participant in the downregulation by gp41 of chemokine receptors.

\section{Discussion}

This study, to our knowledge, represents the first observation that the HIV-1 envelope gp41 interacts with CD4 on monocytes at nanomolar concentrations, and is a potent inhibitor of chemokine receptor expression and function. In our studies we used recombinant gp41 from the laboratory adapted MN strain of HIV-1, which nevertheless reacts with antibodies present in the serum of HIV-1-infected patients. In addition, the ectodomains of gp41 from two other T cell tropic HIV-1, IIIB and HXB2, after incubation with monocytes, also markedly reduced the cell surface expression and function of CXCR4 and CCR5 (data not shown). Although gp41 derived from monocyte tropic HIV-1 was not available to us, our observations demonstrate that gp41 derived from $\mathrm{T}$ cell strains could affect both CXC4 and CCR5, suggesting that the effect is not restricted by the viral tropism. Moreover, since gp41 also inhibited monocyte responses to MCP-1, MCP-3, and fMLP, ligands that do not use major HIV-1 fusion cofactors CXCR4 or CCR5, gp41 causes a broader suppression of chemoattractant-induced monocyte function.

In our experiments, incubation of monocytes with gp41 for 1-6 h, did not change the mRNA expression of CXCR4 or CCR5, nor did gp41 induce a signicant increase in chemokine protein production or mRNA expression by the cells (data not shown), suggesting that gp41-induced chemoattractant receptor downregulation is not due to overproduction of endogenous chemokines. These results indicate that the effects of gp41 is not occurring at the transcriptional level. It is also unlikely that a cytotoxic effect of gp41 used in our study is responsible for the loss of the capacity of monocytes to bind and to respond to chemokines, since monocytes treated with gp41 for up to $12 \mathrm{~h}$ were viable and did not show evidence of apoptosis as judged by FACS analysis. The suppressive effect of gp41 on monocyte chemoattractant receptors is neutralized by an anti-gp41 $\mathrm{mAb}$, suggesting that a contaminant was not responsible (data not shown). In addition, when monocytes were extensively washed after incubation with gp41, the capacity of the cells to bind chemokines recovered within 3-6 h (data not shown). These observations suggest that the suppression of chemoattractant receptors by gp41 most closely resembles a process of heterologous desensitization, but in an atypical fashion, since it involved the participation of CD4. 
Table III. Staurosporine and Calphostin C Partially Reverse the Inhibitory Effect of gp41 on Monocyte Expression of Chemokine-Binding Sites*

\begin{tabular}{|c|c|c|c|c|c|c|c|c|}
\hline \multirow[b]{3}{*}{ Chemokine } & \multicolumn{8}{|c|}{ Cell treatment } \\
\hline & \multicolumn{2}{|c|}{ Medium } & \multicolumn{2}{|c|}{ gp41 (MN, 5 nM) } & \multicolumn{2}{|c|}{$\begin{array}{l}\text { Staurosporine } \\
\text { followed by gp } 41^{\ddagger}\end{array}$} & \multicolumn{2}{|c|}{$\begin{array}{c}\text { Calphostin C } \\
\text { followed by gp } 41^{\S}\end{array}$} \\
\hline & $\mathrm{K}_{\mathrm{d}}(\mathrm{nM})$ & Sites/cell & $\mathrm{K}_{\mathrm{d}}(\mathrm{nM})$ & Sites/cell & $\mathrm{K}_{\mathrm{d}}(\mathrm{nM})$ & Sites/cell & $\mathrm{K}_{\mathrm{d}}(\mathrm{nM})$ & Sites/cell \\
\hline MIP-1 $\beta$ & 1.1 & 9600 & 1.2 & $2700^{\|}$ & 0.9 & $4800^{\mathbb{\pi}}$ & - & - \\
\hline MIP-1 $\beta$ & 1.2 & 8100 & 1.1 & $4320 \|$ & - & - & 1.9 & $6370^{\text {I }}$ \\
\hline SDF- $1 \alpha$ & 6.0 & 10607 & 6.0 & $4100^{\|}$ & 4.0 & $8400^{\mathbb{\pi}}$ & - & - \\
\hline SDF- $1 \alpha$ & 4.0 & 9960 & 6.0 & $3300^{\|}$ & - & - & 4.0 & $4320^{\text {q }}$ \\
\hline MCP-1 & 1.1 & 9153 & 0.8 & $2228 \|$ & 1.0 & $6684^{\pi}$ & - & - \\
\hline MCP-1 & 0.9 & 6243 & 0.7 & $1999 \|$ & - & - & 1.0 & $4163^{\mathbb{I}}$ \\
\hline
\end{tabular}

*Monocytes were incubated with medium alone or recombinant gp41 ( $\mathrm{MN}, 5 \mathrm{nM})$ for $60 \mathrm{~min}$ at $37^{\circ} \mathrm{C}$. After washing, duplicate aliquots of the cells were incubated with $0.12 \mathrm{nM}$ radioiodinated MIP-1 $\beta$ in the presence of increasing concentrations of unlabeled ligand. The samples were cultured at room temperature for $40 \mathrm{~min}$ and then were harvested and measured for radioactivity. The data were analyzed with LIGAND program. Results are from representive experiments out of 12 performed. ${ }^{*}$ Cells were first preincubated with staurosporine $(10 \mathrm{ng} / \mathrm{ml})$ for 30 min at $37^{\circ} \mathrm{C}$ followed by treatment with gp41. ${ }^{\S}$ Cells were first preincubated with calphostin $\mathrm{C}(100 \mathrm{ng} / \mathrm{ml})$ for $4 \mathrm{~h}$ at $37^{\circ} \mathrm{C}$ under a light followed by treatment with gp $41 . \| P<0.05$ (Student's $t$ test) compared with cells treated with medium alone. " $P<0.05$ (Student's $t$ test) compared with cells treated with gp41 alone.

Although it is known that during the process of cell entry, the envelope protein gp120 of HIV-1 binds to CD4, followed by an interaction with chemokine receptors such as CCR5 and CXCR4, a cellular receptor for gp41 has not been identified to date. While several cellular protein species other than CD4 have been implicated as binding proteins for gp41 (33-36), it is the hydrophobicity of gp41 that is believed to play a major role in membrane fusion by insertion of its amino terminus into target cells $(1,2,6)$. In a recent study (37), Ugolini et al. reported on an initial interaction between gp120 and CD4 on T cells

\section{$C D 4+C \times C R 4+$}

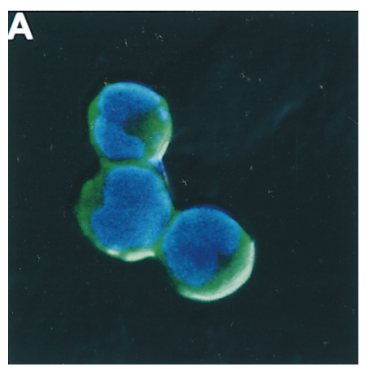

control

CD4 $C X C R 4+$

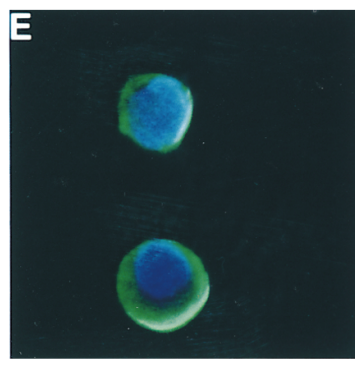

control

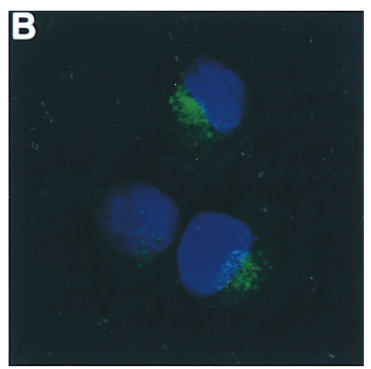

SDF-1 $\alpha(1000 \mathrm{ng} / \mathrm{ml})$

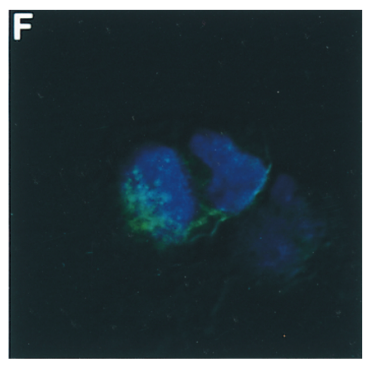

SDF-1 $\alpha(1000 \mathrm{ng} / \mathrm{ml})$

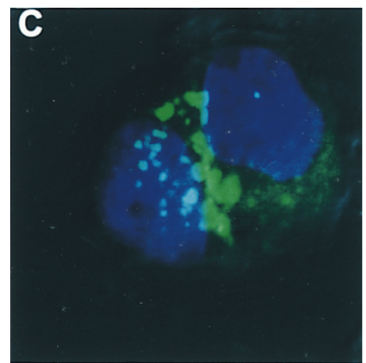

gp41 (MN, 25nM)

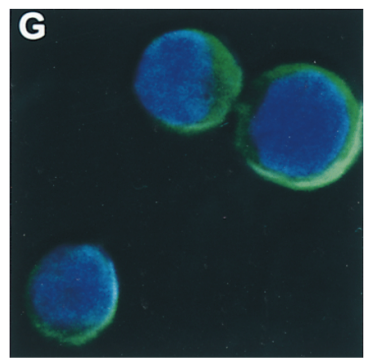

gp41 (MN, 25nM)

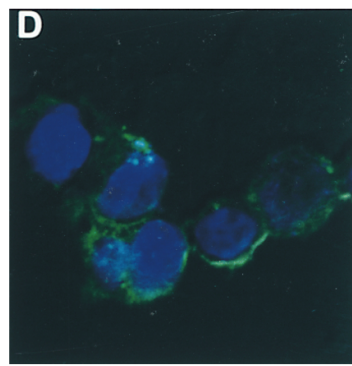

anti-CD4 $(A 6,5 \mu \mathrm{g} / \mathrm{ml})$

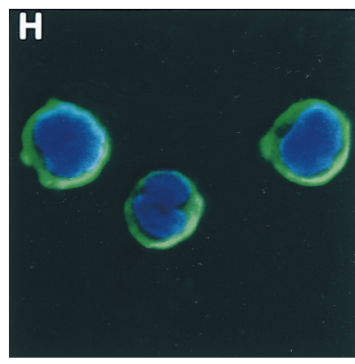

anti-CD4 (A6, 5 $\mu \mathrm{g} / \mathrm{ml})$

Figure 4. Internalization of CXCR4/Fusin in HEK293 cells analyzed by confocal microscopy. HEK293 cells stably expressing CXCR4/Fusin were transiently with or without cotransfection with CD4 were treated with various agents and the localization of CXCR4/Fusin was visualized by confocal microscopy. FITC staining shows CXCR4/Fusin expressing on the surface of the cells treated with medium (control) $(A$ and $E)$, but are internalized into the perinuclear cytoplasma in response to the native ligand of CXCR4, SDF- $1 \alpha(1 \mu \mathrm{g} / \mathrm{ml})$, in both CD4 $4^{-}(B)$ and CD4 $4^{+}(F)$ cells. Gp41 (MN, $25 \mathrm{nM})$ and anti-CD4 $(5 \mu \mathrm{g} / \mathrm{ml})$ resulted in internalization of CXCR4/Fusin in cells coexpressing CD4 $(G$ and $H)$, but not in $\mathrm{CD} 4^{-}$cells $(C D)$. Three experiments yielded identical results. 
Table IV. Gp41 Downregulates ${ }^{125}$ I-MIP-1 $\beta$ Binding to CCR5/293 Cells Expressing Intact CD4*

\begin{tabular}{|c|c|c|c|c|}
\hline \multirow[b]{3}{*}{ Cell type } & \multicolumn{4}{|c|}{ Counts per minute (\% inhibition of binding) } \\
\hline & \multicolumn{4}{|c|}{ Preincubation of cells with } \\
\hline & $\begin{array}{c}\text { Medium } \\
\text { (binding in the absence of cold MIP-1 } \beta \text { ) }\end{array}$ & $\begin{array}{c}\text { Medium }^{\ddagger} \\
\text { (binding in the presence of cold MIP-1 } \beta \text { ) }\end{array}$ & gp41 (MN, 25 nM) & Anti-CD4 (A6, $10 \mu \mathrm{g} / \mathrm{ml})$ \\
\hline CCR5/293 & 4435 & $1101(75)^{\S}$ & $4735(0)$ & $4634(0)$ \\
\hline Control vaccinia vector & 5927 & $1371(74)^{\S}$ & $5467(8)$ & $5452(8)$ \\
\hline VCB2 (Tailless CD4) & 4203 & $1449(66)^{\S}$ & $3745(11)$ & $3981(5)$ \\
\hline VCB7 (Intact CD4) & 4217 & $1027(76)^{\S}$ & $1576(62)^{\S}$ & $1991(53)^{\S}$ \\
\hline
\end{tabular}

*CCR5/293 cells were infected with control vaccinia virus, or recombinant vaccinia virus encoding tailless CD4 (VCB2) or intact $\mathrm{CD} 4(\mathrm{VCB} 7)$ at $37^{\circ} \mathrm{C}$ for $1 \mathrm{~h}$, at multiplicity of infection of $5 \mathrm{in}$ DME containing $2 \% \mathrm{FCS}$ and antibiotics. The cells were washed and were cultured for $10 \mathrm{~h}$ at $37^{\circ} \mathrm{C}$ in $\mathrm{DME}$ containing $10 \%$ FCS, and antibiotics. The cells were then gently detached with trypsin/EDTA, resuspended in binding medium, aliquoted, and incubated for $10 \mathrm{~h}$ in the presence or absence of gp 41 or anti-CD $4 \mathrm{mAb}$. Binding assays using ${ }^{125}$ I-MIP-1 $\beta$ were performed at room temperature for 40 min. ${ }^{\ddagger}$ Cells were preincubated with medium and binding was performed in the presence of $120 \mathrm{nM}$ unlabeled MIP-1 $13 .{ }^{8}$ Significant inhibition of ${ }^{125} \mathrm{I}$ MIP-1 $\beta$ binding compared with cells preincubated with medium alone $(P<0.05)$.

that subsequently recruited and internalized CXCR4. However, gp41 was not reported to have such an interaction with CD4. On the other hand, the binding of gp160 to soluble CD4 did change the structure of gp120 and gp41, facilitating their interaction with target cells (38). Our results suggest that CD4 on monocytes also functions as a receptor for gp 41, as demonstrated by: (i) the reduction by soluble CD4 of the suppressive effect of gp41; and (ii) the observation that the effect of gp41 was detected only on $\mathrm{CD}^{+}$monocytes and 293 cells expressing both CD4 and chemokine receptors. (iii) Unlabeled gp41 competes with radiolabeled gp120 for binding to CD4, although with a relatively lower affinity than gp120 itself (Ueda et al., data not shown). These results suggest that gp41 indeed interacts with cellular CD4 to negatively regulate the expression and function of chemoattractant receptors.

How does interaction of gp 120 or gp 41 with CD4 result in suppression of chemokine receptor expression and functions? CD4 was originally identified as a phenotypic marker and subsequently a high-affinity receptor for HIV-1 envelope protein gp120 $(3,4)$. CD4 also facilitates T cell function by binding to the nonpolymorphic region of the MHC class II antigens expressed on the surface of antigen presenting cells. A suppressive role for CD4 in the activation of T lymphocytes was indicated by the observations that anti-CD4 antibodies inhibited a variety of T lymphocyte effector functions in vitro (reviewed in ref. 39). CD4 contributes directly to signal transduction by its cytoplasmic domain through association with the $s r c$-like protein tyrosine kinase $\mathrm{p} 56^{\text {lck }}$ in T lymphocytes (39). Expression of activated $l c k$ in turn has been shown to downregulate the T cell receptor (40). However, the precise role of CD4 on monocytes/macrophages is unclear except for its capacity to act as a receptor for IL-16 (41) and as a fusion cofactor for monocyte tropic strain of HIV-1.

Although $\mathrm{G}$ protein-mediated signaling is not involved in HIV-1 entry, the ability of HIV-1 evelope proteins to induce cell signaling has been well documented. Gp160 of the monocyte tropic HIV-1 induced chemotaxis and $\mathrm{Ca}^{2+}$ mobilization in $\mathrm{CD}_{4} / \mathrm{CCR}^{+} \mathrm{T}$ lymphocytes (42), and the interaction of HIV-1 envelope protein with CCR5 or CXCR4 in the presence of CD4-activated protein tyrosine kinase (43). The activation of $\mathrm{PKC}$ has been reported to be a crucial signaling pathway that mediates the cross-desensitization of $\mathrm{G}$ protein-coupled receptors (44) and ligation of cellular CD4 by gp120 or anti-CD4 antibody could lead to PKC activation $(45,46)$. PMA, a potent PKC activator, which desensitizes a variety of chemoattractant receptors, was reported to downregulate HIV-1 fusion cofactor CXCR4 and its effect was reversed by the PKC inhibitor staurosporine $(32,47)$. We also found that, like gp41 in this study, gp120 of the various HIV-1 strains downregulated chemokine receptor expression on monocytes. Monocytes pretreated with staurosporine were resistant to the inhibitory effect of gp120 (47a). Our experiments indicated that gp41, as well as gp120 and anti-CD4 antibody, all stimulated the activation of PKC in monocytes (Evans et al., data not shown) suggesting that PKC activation plays an important role in HIV-1 envelope-induced chemokine receptor downregulation in monocytes. Although unlike gp120 which was moderately chemotactic for monocytes (data not shown), gp41 did not mobilize monocytes, gp41 does have other cell-activating effects, as demonstrated by its ability to induce proinflammatory cytokines and nitric oxide synthase in phagocytic cells and glial cells (11-15). Our present observation provides strong evidence that the suppressive effect of gp41 on monocyte chemoattractant receptors is dependent on PKC-mediated cell activation.

The in vivo pathophysiological significance of the suppression of chemokine receptors by gp41 remains to be determined. Monocytes isolated from HIV-1 infected individuals showed remarkably reduced chemotactic response to a number of chemoattractants (9). The HIV-1 envelope gp120 has been reported to cause the downregulation of the receptors for fMLP and C5a (10) and we have shown that a variety of chemokine receptors are suppressed by gp120 in association with reduced cell migration to these chemoattractants (47a). Although the effect of gp 41 on immune cells in vivo is yet to be clarified, the available evidence suggests that gp41 interacts with host cells and induces potent host-antibody responses. During viral fusion, the envelope gp120 is proteolytically cleaved from gp41 after binding to cellular coreceptors leading to the exposure of gp41 (48), which presents a fusion domain to the cell membrane. In addition, anti-gp41 antibodies can be detected in early stages of HIV-1 infection when the viral titer 
has passed its peak (48). Furthermore, gp41 has been implicated as a major causal factor of AIDS-associated dementia and antigenic gp41 but not gp120, was detected in patients' brain tissue (16). Therefore, the inhibitory effects of gp41 on chemoattractant receptors and its ability to modulate Th2 cytokine production may have in vivo relevance in AIDS-associated immune suppresion $(15-17,19)$. Further experiments are being performed in this laboratory to investigate the effect of epitopes from gp41 on chemokine receptor expression and function. We observed that a gp41 peptide segment that has been shown to inhibit HIV-1 entry and replication (49) potently activates human monocytes through a $\mathrm{G}$ protein-mediated signaling pathway, supporting the notion that gp41 may downregulate chemoattractant receptors by a heterologous desensitization mechanism. Since chemokines are involved in many pathological states $(21,22)$, design of inhibitory agents based on the HIV-1 envelope proteins may lead to the development of therapeutic modalities for treatment of chemokinemediated pathology.

\section{Acknowledgments}

The authors thank Dr. P. Gray for supplying us with CCR3- and CCR5-transfected HEK 293 cells, Dr. C. Broder for vaccinia viruscontaining tailless and intact CD4, and Dr. J. Resau for assistance in confocal microscopy. We also gratefully acknowledge the technical support of Ms. K. Bengali, Ms. N. Dunlop, Ms. L. Finch, and the clerical assistance of Ms. C. Fogle.

\section{References}

1. Willey, R.L., J.S. Bonifacino, B.J. Potts, M.A. Martin, and R.D. Klausner. 1988. Biosynthesis, cleavage, and degradation of the human immunodeficiency virus 1 envelope glycoprotein gp160. Proc. Natl. Acad. Sci. USA. 85: 9580-9584.

2. Freed, E.O., and M.A. Martin. 1995. The role of human immunodeficiency virus type 1 envelope glycoproteins in virus infection. J. Biol. Chem. 270: 23883-23886.

3. Klatzmann, D., E. Champagne, S. Chamaret, J. Gruest, D. Guetard, T. Hercend, J.C. Gluckman, and L. Montagnier. 1984. T-lymphocyte T4 molecule behaves as the receptor for human retrovirus LAV. Nature. 312:767-768.

4. Dalgleish, A.G., P.C.L. Beverley, P.R. Clapham, D.H. Crawford, M.F. Greaves, and R.A. Weiss. 1984. The CD4 (T4) antigen is an essential component of the receptor for the AIDS retrovirus. Nature. 312:763-767.

5. Moore, J.P., and A. Trokola. 1997. HIV type 1 coreceptors, neutralization serotypes, and vaccine development. AIDS Res. Hum. Retroviruses. 13: $733-736$.

6. Chan, D.C., D. Fass, J.M. Berger, and P.S. Kim. 1997. Core structure of gp41 from the HIV envelope glycoprotein. Cell. 89:263-273.

7. Stein, B., S. Gowda, J. Lifson, R. Penhallow, K. Bensch, and E. Engelmann. 1987. $\mathrm{pH}$ independent HIV entry into CD4-positive T cells via virus envelope fusion to the plasma membrane. Cell. 50:327-328.

8. Freed, E.O., D.J. Myers, and R. Risser. 1990. Characterization of the fusion domain of the human immunodeficiency virus type 1 envelope glycoprotein gp41. Proc. Natl. Acad. Sci. USA. 87:4650-4654.

9. Smith, P.D., K. Ohura, H. Masur, H.C. Lane, A.S. Fauci, and S.M. Wahl. 1984. Monocyte function in the acquired immune deficiency syndrome. J. Clin. Invest. 74:2121-2128.

10. Wahl, S.M., J.B. Allen, S. Gartner, J.M. Orenstein, M. Opovic, D.E. Chenoweth, L.O. Arthur, W.L. Farrar, and L.M.J. Wahl. 1989. HIV-1 and its envelope glycoprotein down-regulate chemotactic ligand receptors and chemotactic function of peripheral blood monocytes. J. Immunol. 142:3553-3559.

11. Koka, P., K. He, J.A. Zack, S. Kitchen, W. Peacock, I. Fried, T. Tran, S. Yashar, and J.E. Merrill. 1995. Human immunodeficiency virus 1 envelope proteins induce interleukin 1, tumor necrosis factor $\alpha$, and nitric oxide in glial cultures derived from fetal, neonatal, and adult human brain. J. Exp. Med. 182: 941-952.

12. Merrill, J.E., Y. Koyanagi, J. Zack, L. Thomas, F. Martin, and I.S.Y. Chen. 1992. Induction of interleukin-1 and tumor necrosis factor alpha in brain cultures with human immunodeficiency virus type 1. J. Virol. 66:2217-2225.

13. Koka, P., K. He, D. Camerini, T. Tran, S.S. Yashar, and J.E. Merrill. 1995. The mapping of HIV-1 gp160 epitopes required for IL-1 and TNF $\alpha$ pro- duction in glial cells. J. Neuroimmunol. 57:179-191.

14. Merrill, J.E., and O. Martinez-Maza. 1993. Cytokines in AIDS-associated neurons and immune system dysfunction. In Neurobiology of Cytokines. Part B: Methods in Neuroscience. De Souza, E.B., editor. Academic Press, Inc., San Diego, CA. 243-266.

15. Takeshita, S., E.C. Breen, M. Ivashchenko, P.G. Nishanian, T. Kishimoto, D.L. Vredevoe, and O. Martinez-Maza. 1995. Induction of IL-6 and IL-10 production by recombinant HIV-1 envelope glycoprotein 41 (gp41) in the THP-1 human monocytic cell line. Cell. Immunol. 165:234-242.

16. Adamson, D.C., B. Wildemann, M. Sasaki, J.D. Glass, J.C. McArthur, V.I. Christov, T.M. Dawson, and V.L. Dawson. 1996. Immunologic NO synthase: elevation in severe AIDS dementia and induction by HIV-1 gp41. Science. 274:1917-1921.

17. Chen, Y.-H., A. Christiansen, and M.P. Dierich. 1995. HIV-1 gp41 selectively inhibits spontaneous cell proliferation of human cell lines and mitogenand recall antigen-induced lymphocyte proliferation. Immunol. Lett. 48:39-44.

18. Koutsonikolis, A., S. Haraguchi, E.N. Brigino, U.E. Owens, R.A. Good, and N.K. Day. 1997. HIV-1 recombinant gp41 induces IL-10 expression and production in peripheral blood monocytes but not in T-lymphocytes. Immunol. Lett. 55:109-113.

19. Haraguchi, S., R.A. Good, M. James-Yarish, G.J. Cianciolo, and N. Day. 1995. Differential modulation of Th1- and Th2-related cytokine mRNA expression by a synthetic peptide homologous to a conserved domain within retroviral envelope protein. Proc. Natl. Acad. Sci. USA. 92:3611-3615.

20. Haraguchi, S., R.A. Good, G.J. Cianciolo, R.W. Engelman, and N.K. Day. 1997. Immunosuppressive retroviral peptides: immunological implications for immunosuppressive influence of retroviral infections. J. Leukocyte Biol. 61 : 654-666.

21. Baggiolini, M., B. Deward, and B. Moser. 1994. Interleukin-8 and related chemotactic cytokines-CXC and CC chemokines. Adv. Immunol. 55:97178.

22. Oppenheim, J.J., J.M. Wang, O. Chertov, D.D. Taub, and A. BenBaruch. 1996. The role of chemokines in transplantation biology. In Cellular and Molecular Aspects. N.L. Tilney, T.B. Strom, and L.C. Paul, editors. Philadelphia, Lippincott-Raven. 182-200.

23. Xu, L.L., D.W. McVicar, A. Ben-Baruch, D.B. Kuhns, J. Johnston, J.J. Oppenheim, and J.M. Wang. 1995. Monocyte chemotactic protein-3 (MCP-3) interacts with multiple leukocyte receptors: binding and signaling of MCP-3 through shared as well as unique receptors on monocytes and neutrophils. Eur. J. Immunol. 25:2612-2617.

24. Ben-Baruch, A., L. Xu, P.R. Young, K. Bengali, J.J. Oppenheim, and J.M. Wang. 1995. Monocyte chemotactic protein-3 (MCP-3) interacts with multiple leukocyte receptors. C-C CKR1, a receptor for macrophage inflammatory protein-1 $\alpha /$ RANTES, is also a functional receptor for MCP3. J. Biol. Chem. 270:22123-22128.

25. Combadiere, C., S.K. Ahuja, H.L. Tiffany, and P.M. Murphy. 1996 Cloning and functional expression of CC CKR5, a human monocyte CC chemokine receptor selective for MIP- $1 \alpha$, MIP-1 $\beta$ and RANTES. J. Leukocyte Biol. 60:147-152.

26. Samson, M., O. Labbe, C. Mollerau, G. Vassart, and M. Parmentier. 1996. Molecular cloning and functional expression of a new human CCchemokine receptor gene. Biochemistry. 35:3362-3367.

27. Raport, C.J., J. Gosling, V.L. Schweickart, P.W. Gray, and I.F. Charo. 1996. Molecular cloning and functional characterization of a novel human CC chemokine receptor (CCR5) for RANTES, MIP-1 $\beta$ and MIP-1 $\alpha$. J. Biol. Chem. 271:17161-17166.

28. Neote, K., D. DiGregorio, J.Y. Mak, R. Horuk, and T.J. Schall. 1993. Molecular cloning, functional expression, and signaling characteristics of a C-C chemokine receptor. Cell. 72:415-425.

29. Gao, J.L., D.B. Kuhns, H.L. Tiffany, D. McDermot, X. Li, U. Francke, and P.M. Murphy. 1993. Structure and functional expression of the human macrophage inflammatory protein $1 \alpha$ /RANTES receptor. J. Exp. Med. 177:14211427.

30. Franci, C., L.M. Wong, J. Van Damme, P. Proost, and I.F. Charo. 1995. Monocyte chemoattractant protein-3, but not monocyte chemoattractant protein-2, is a functional ligand of the the human monocyte chemoattractant protein-1 receptor. J. Immunol. 154:6511-6517.

31. Combadiere, C., S.K. Ahuja, J. Van Damme, H.L. Tiffani, J.-L. Gao, and P.M. Murphy. 1995. Monocyte chemoattractant protein-3 is a functional ligand for CC chemokine receptors 1 and 2B. J. Biol. Chem. 270:29671-29675.

32. Golding, H., J. Manischewitz, L. Vujcic, R. Blumenthal, and D.S. Dimitrov. 1994. The phorbol ester phorbol myristate acetate inhibits human immunodeficiency virus type 1 envelope-mediated fusion by modulating an accessory component (s) in CD4-expressing cells. J. Virol. 68:1962-1969.

33. Quresshi, N.M., D.H. Coy, R.F. Garry, and L.A. Henderson. 1990. Characterization of a putative cellular receptor for HIV-1 transmembrane glycoprotein using synthetic peptides. AIDS. 4:553-558.

34. Chen, Y.-H., C. Ebenbichler, R. Vornhagen, T.F. Schulz, F. Steindl, G. Bock, H. Katinger, and M.P. Dierich. 1992. HIV-1 gp41 contains two sites for interaction with several proteins on the helper T-lymphoid cell line, H9. AIDS. 6:533-539.

35. Chen, Y.-H., and M.P. Dierich. 1996. Identification of a second site in 
HIV-1 gp41 mediating binding to cells. Immunol. Lett. 52:153-156.

36. Ebenbichler, C.F., H. Stoiber, R. Schneider, J.R. Patsch, and M.P. Dierich. 1996. The human immunodeficiency virus type 1 transmembrane gp41 protein is a calcium-binding protein and interacts with the putative secondreceptor molecules in a calcium-dependent manner. J. Virol. 70:1723-1728.

37. Ugolini, S., M. Moulard, I. Mondor, N. Barois, D. Demandolx, J. Hoxie, A. Brelot, M. Alizon, J. Davoust, and Q.J. Sattentau. 1997. HIV-1 gp120 induces an association between CD4 and the chemokine receptor CXCR4. J. Immunol. 159:3000-3008.

38. Demaria, S., and Y. Bushkin. 1996. Soluble CD4 induces the binding of human immunodeficiency virus type 1 to cells via the V3 loop of glycoprotein 120 and specific sites in glycoprotein 41. AIDS Res. Hum. Retroviruses. 12:281290.

39. Ravichandran, K.S., T.L. Collins, and S.J. Burakoff. 1996. CD4 and signal transduction. Curr. Top. Microbiol. Immunol. 205:47-62.

40. D’Oro, U., M.S. Vacchio, A.M. Weissman, and J.D. Ashwell. 1997. Activation of the Lck tyrosine kinase targets cell surface T cell antigen receptors for lysosomal degradation. Immunity. 7:619-628.

41. Center, D.M., H. Kornfeld, and W.W. Cruikshank. 1996. Interleukin 16 and its function as a CD4 ligand. Immunol. Today. 17:476-481.

42. Weissman, D., R.L. Rabin, J. Arthos, A. Rubbert, M. Dybul, R. Swofford, S. Venkatesan, J.M. Farber, and A.S. Fauci. 1997. Macrophage-tropic HIV and SIV envelope proteins induce a signal through the CCR5 chemokine receptor. Nature. 389:981-985.

43. Davis, C.B., I. Dikic, D. Unutmaz, C.M. Hill, J. Arthos, M.A. Siani, D.A. Thompson, J. Schlessinger, and D.R. Littman. 1997. Signal transduction due to HIV-1 envelope interactions with chemokine receptors CXCR4 or CCR5. J. Exp. Med. 186:1793-1798.

44. Richardson, R.M., H. Ali, E.D. Tomnave, B. Haribabu, and R. Snyderman. 1995. Cross-desensitization of chemoattractant receptors occurs at multiple levels. J. Biol. Chem. 270:27829-27833.

45. Parada, N.A., W.W. Cruikshank, H.L. Danis, T.C. Ryan, and D.M. Center. 1996. IL-16- and other CD4 ligand-induced migration is dependent upon protein kinase C. Cell. Immunol. 168:100-106.

46. Wahl, L.M., M.L. Corcoran, S.W. Pyle, L.O. Arthur, A. Harel-Bellan, and W.L. Farrar. 1989. Human immunodeficiency virus glycoprotein (gp120) induction of monocyte arachidonic acid metabolites and interleukin 1. Proc. Natl. Acad. Sci. USA. 86:621-625.

47. Lapham, C.K., J. Ouyang, B. Chandrasekhar, N.Y. Nguyen, D.S. Dimitrov, and H. Golding. 1996. Evidence for cell-surface association between fusin and the CD4/gp120 complex in human cell lines. Science. 274:602-605.

47a. Wang, J.M., H. Ueda, O.M.Z. Howard, M.C. Grimm, O. Chertov, X. Gong, W. Gong, J.H. Resau, C.C. Broder, G. Evans, et al. 1998. HIV-1 envelope gp120 inhibits monocyte response to chemokines through $\mathrm{CD}_{4}$ signaldependent chemokine receptor down-regulation. J. Immunol. In press.

48. Nara, P.L., R.R. Garrity, and J. Goldsmith. 1991. Neutralization of HIV: a paradox of humoral proportions. FASEB (Fed. Am. Soc. Exp. Biol.) J. 5:2437-2455.

49. Wild, C.T., D.C. Shgars, T.K. Greenwell, C.B. McDanal, and T.J. Mathews. 1994. Peptides corresponding to a predictive a-helical domain of human immunodeficiency virus type $1 \mathrm{gp} 41$ are potent inhibitors of virus infection. Proc. Natl. Acad. Sci. USA. 91:9770-9774. 